\title{
Impact of Price and Price Variability on Acreage Allocation in Rice and Wheat Production in Bangladesh
}

\author{
Basanta Kumar Barmon* and Muntasir Chaudhury \\ Department of Economics, East West University, Aftabnagar, Dhaka, Bangladesh \\ *Corresponding author and Email: bkbarmon@yahoo.com
}

Received: 16 November $2011 \quad$ Accepted: 26 May 2012

\begin{abstract}
The present study was conducted to estimate the impacts of price and price variability on acreage allocation of rice and wheat production in Bangladesh. Time series data of price and acreage allocation of rice and wheat production during 1983-84 to 2007-08, collected from Bangladesh Bureau of Statistics (BBS) were used in this study. Compound growth rate and Nerlovian models were used. The study indicated that the wholesale price of rice and wheat had significant impact on the allocation of land for rice and wheat production. Significant price variability was found both in case of rice and wheat crop in short-run (SR) and long-run (LR). The values of Nerlovian coefficients of adjustment were found low, which means that although the farmers were adjusting to the changing levels of price, price variability, yield, etc the adjustment was not rapid. Therefore, it may be concluded that the price of rice and wheat should be adjusted rapidly along with allocation of rice and wheat production in Bangladesh.
\end{abstract}

\section{Keywords: Price variability, acreage allocation, rice and wheat production, Bangladesh}

\section{Introduction}

Rapid population growth, increased food demand, and urbanization are exerting tremendous pressure on agricultural land, making it an increasingly scarce resource (Barmon et al., 2007). Besides, agricultural land is being transformed to non-agricultural $(80,000$ hectares per year) uses that hamper agricultural production. Hence, per capita agricultural land (12.5 decimals) is declining over the years in Bangladesh (Quasem, 2011). Food insecurity is a severe concern since the independence of Bangladesh, although there is a distinct progress in rice production in the recent years. The government of Bangladesh imports a large amount of rice from aboard to meet up the domestic demand. The total import of food grains has gone up from 3.013 million tons ( 0.603 million tons of rice and 2.41 million tons of wheat) in 2008-09 to 3.45 million tons $(0.087$ million tons of rice and 3.36 million tons of wheat) in 2009-2010 (BER, 2011). Rice is the main staple food and dominant crop in Bangladesh and it is grown on more than threefourths of the total cultivable land. Food selfsufficiency mostly depends on rice production. The total contribution of the rice production is about $70 \%$ of the total agricultural contribution to GDP (BBS, 2009). Thus, it is often argued that self-sufficiency in food might be attained by enhancing the overall productivity of rice. The contribution of rice to self-sufficiency in food is enormous because currently rice is grown on around 10.80 million hectares that covers about $78 \%$ of the total cultivable land in Bangladesh 
(BBS, 2009). Besides, rice provides $76 \%$ of the people's average calorie intake and $66 \%$ of protein intake consumption (Dey et al., 1996).

In Bangladesh, several research works have been conducted on different aspects of seasonal fluctuation, trends and price variability of rice by using secondary data (Shahabuddin, 1992; Ahmed and Bernard, 1989; Dorosh and Shahabuddin, 2002). Also, primary and secondary data have been used to perform multiple research works to visualize the impact of price variability on the acreage allocation of rice (Singh et al., 1974; Singh and Kumar, 1976; Kaul, 1967; Kaul and Sidhu, 1971) and other agricultural crops during the sixties and seventies in India (Lalit and Kahlon, 1969; Sahay, 1971; Acharya and Bhatia, 1974; Devi and Rajagopalan, 1965; Rao and Krisna, 1965). However, the impacts of wholesale market price of rice and wheat as well as the price variabilities on the allocation of rice and wheat production in Bangladesh have received less attention. The present study was therefore, undertaken to determine the effect of price and price variabilities on the allocation of land for the production of rice and wheat in Bangladesh. The results obtained from the study will assist policymakers and researchers to devise appropriate policies and take necessary measures, in order to stimulate and stabilize food security in Bangladesh.

\section{Methodology and Analytical Techniques}

Sources of data and analytical techniques are briefly presented in this section.

\subsection{Source of data}

This study aims to analyse the impacts on price and price variability on acreage allocation in rice production in Bangladesh. Secondary data were used in this study and the data were collected from various issues of Bangladesh Bureau of Statistics (BBS, 1994-95, 2002-03, and 2007-08).

\subsection{Analytical techniques}

Two models - compound growth rate and Nerlovian model were used to estimate growth rate of price and allocation of acreage, and shortrun and long-run price variabilities of rice and wheat production in Bangladesh.

\subsubsection{Compound growth rate model}

On the basis of the objectives, different growth rate models such as linear regression model, semi-log model, double-log model, log-log inverse model and reciprocal model have been run. However, the double-log model seemed to be the most appropriate one to analyze the data. An exponential function of the following form was fitted to the data to compute the growth rates of areas and yield of fine, medium and coarse rice and wheat:

$Y_{i t}=a_{i} e^{b_{i} t}$

or $\ln Y_{i t}=\ln a_{t}+b_{i} t \quad(i=1$, and $2 \quad$ and $t=1,2 \ldots \ldots .24)$

Where, $\ln =$ Natural logarithm and $\mathrm{b}$ is the growth rate. Percentage of exponential growth rate was expressed by multiplying b with 100 . Such a model was used to estimate the growth performances of different varieties in Bangladesh (Alam, 1992).

\subsubsection{Nerlovian model}

In the present study, a model of the Nerlovian type (Nerlove, 1958) has been used in the simplest form and it is based on the relations:

$$
A_{t}^{*}=a+b p_{t-1}+U_{t} \ldots \ldots \ldots \ldots \ldots \ldots \ldots \ldots \ldots \ldots \ldots \ldots .(1)
$$$$
A_{t}-A_{t-1}=\delta\left(A_{t}^{*}-A_{t-1}\right) ; \quad 0 \leq \delta \leq 1 \ldots \ldots \ldots \ldots .(2)
$$

The reduced forms of the above equations are as follows:

$A_{t}=A_{0}+A_{t} P_{t-1}+A_{2} A_{t-1}+V_{t} \ldots \ldots \ldots \ldots \ldots \ldots \ldots$. B $)$

Where,

$A_{t}^{*}=$ desired acreage in time $\mathrm{t}$

$A_{0}=a \delta, \quad A_{1}=b \delta, \quad A_{2}=(1-\delta) \quad$ and $\quad V_{t}=\delta U_{t}$

The coefficient of " $\delta$ " is known as the Nerlovian coefficient of adjustment and is based on the 
Hick's price elasticity of expectations. This coefficient indicates how fast the farmers are adjusting to their expectations. The value of coefficient of adjustment $(\delta)$ lies between 0 and 1 . A value of $\delta$ near to " 0 " indicates that the farmers are very slowly adjusting to the changing prices and other factors. The equivalent of $\delta$ close to one indicates that the farmers are adjusting very quickly to the changing prices and other factors.

The functional form was considered as:

$A_{t}=f\left(Y_{t-1}, A_{t-1}, P_{t-1}\right)$

Where,

$A_{t}=$ Area (acre) under the cultivation of paddy at $\mathrm{t}^{\text {th }}$ time

$\mathrm{Y}_{\mathrm{t}-1}=$ Yield of the paddy $(\mathrm{kg} / \mathrm{acre})$ at $(\mathrm{t}-1)^{\mathrm{th}}$ period

$\mathrm{P}_{\mathrm{t}-1}=$ Price of paddy $(\mathrm{taka} / \mathrm{kg})$ at $(\mathrm{t}-1)^{\mathrm{th}}$ period.

Coefficient of variation (COV) was used to examine the price variability of short-run (SR) and long-run (LR). A small value of COV indicates that the price of rice is very close to mean and large $\mathrm{COV}$ indicates that price is widely spread from the mean over the year. In other words, small COV means less price variability and large $\mathrm{COV}$ indicates greater price variability over the year.

Two types of regression models - linear and logarithmic were run to estimate the regression coefficients; however, logarithmic forms were better fitted for estimation.

\section{Results and Discussion}

The growth performances of wholesale price of main food grain rice and wheat are presented in Table 1. It shows that the wholesale of fine rice, medium rice and coarse rice was increased significantly at 1 per cent level from the period 1983-84 to 2007-08. It was found that wholesale price was increased more rapidly of fine rice compared to medium and coarse rice. The main reason was that most of the people of Bangladesh are poor and they mainly depend on medium and coarse rice for their daily meal, and the government always tries to control the market price of medium and coarse rice considering the buying capacity of poor people.

The growth rate of wholesale market price of wheat has been increased more rapidly than wholesale price of fine, medium and coarse rice in Bangladesh. One of the main reasons is that usually farmers use their land for rice production rather than wheat production. However, during the last one decade domestic demand was higher than domestic supply (production). As a result, wholesale market price of wheat has increased more rapidly compared to the wholesale price of rice.

Table 1. Exponential growth rate of wholesale and retail price of fine, medium and coarse rice for the period 1983-84 to 2007-08

\begin{tabular}{|c|c|c|c|c|}
\hline & Coefficients & $\mathrm{R}^{2}$ & t-statistic & $\mathrm{D}-\mathrm{W}$ \\
\hline Fine rice & $0.039811 * * *$ & 0.86 & 11.74 & 0.69 \\
\hline Medium rice & $0.034433 * * *$ & 0.87 & 12.45 & 1.05 \\
\hline Coarse rice & $0.034098 * * *$ & 0.79 & 9.18 & 1.07 \\
\hline Wheat & $0.057 * * *$ & 0.81 & 9.10 & 1.32 \\
\hline
\end{tabular}

Notes: (i) $* * *$ indicate $1 \%$ level of significance.

(ii) D-W indicates Durbin-Watson statistic. 


\subsection{Estimates of multiple regression model}

The multiple regression models included lagged acreage $\left(\mathrm{A}_{\mathrm{t}-1}\right)$, price $\left(\mathrm{P}_{\mathrm{t}-1}\right)$, yield $\left(\mathrm{Y}_{\mathrm{t}-1}\right)$, and time trend as the independent variables, while acreage was considered as dependent variable. The effects of lagged variables acreage, price, yield, and time trend on allocation of land for rice are presented in Tables 2 and 3.

\subsubsection{Rice production}

\section{Lagged acreage}

Agricultural production mainly depends on the price variability and yield. Fluctuations of prices reflect the imperfect conditions of marketing system. Variabilities in yield, on the other hand, are caused by the weather conditions and technology. Table 2 shows that all the coefficients in the regression model have expected signs. The lagged variables acreage had significant effect on allocation of land for all types of rice and all coefficients were statistically significant at $1 \%$ level. Table 2 also shows that other lagged variables such as price variability, yield and time have significant expected effects on land allocation for rice except coarse rice. The negative coefficient of trends of wholesale price indicated an up-word shift in the allocation of area for rice production.

\section{Lagged price}

The results of estimated regression analysis (Table 2) show that the wholesale price of fine and medium rice had significant impacts on the allocation of land for rice production (significant at 5 per cent level). The wholesale price of coarse rice had comparatively less effect on rice production than those of fine and medium rice. All wholesale price coefficients had negative signs, which indicate up-word shifts in the allocation of land for rice production. The main reason is that farmers are always motivated to cultivate any type of crop production if they are secured by profitable market price.

Table 2. Estimates of regression coefficients of wholesale prices of rice

\begin{tabular}{lccc}
\hline \multirow{2}{*}{ Estimates } & Fine rice & Medium rice & Coarse rice \\
& Coefficients & Coefficients & Coefficients \\
\hline \multirow{2}{*}{ Constant } & -0.600 & -0.507 & 2.187 \\
& $(-0.48)$ & $(-0.41)$ & $(1.57)$ \\
$\ln \mathrm{A}_{\mathrm{t}-1}$ & $0.5805 * * *$ & $0.6337 * * *$ & $0.6126 * * *$ \\
& $(-4.30)$ & $(4.70)$ & $(2.87)$ \\
$\ln \mathrm{P}_{\mathrm{t}-1}$ & $-0.263^{* *}$ & $-0.3015 * *$ & -0.0047 \\
& $(-2.24)$ & $(-2.25)$ & $(-0.03)$ \\
$\ln \mathrm{Y}_{\mathrm{t}-1}$ & $0.6566 * * *$ & $0.5889 * * *$ & 0.1504 \\
& $(3.55)$ & $(3.66)$ & $(0.58)$ \\
$\ln$ time & $0.1603 * * *$ & $0.15222^{* * *}$ & 0.09954 \\
$\mathrm{R}^{2}$ & $(3.26)$ & $(3.17)$ & $(1.49)$ \\
\hline Notes: & 0.98 & 0.98 & 0.96 \\
\hline
\end{tabular}

(i) $* * *$ and $* *$ indicate $1 \%$ and $5 \%$ level of significance, respectively.

(ii) The figures in parentheses indicate t-statistic.

(iii) A, P and Y indicate cropped area, wholesale price and yield, respctively. 


\section{Lagged yield}

As mentioned before that yield mainly depends on weather conditions, availability of inputs and technology. Generally, farmers are motivated to cultivate a particular crops production if they get good yield. In case of wholesale price, the coefficients of yield in the regression models for fine and medium rice production had significant positive impacts on the allocation of land. The coefficient of coarse rice was smaller (statistically insignificant) than those of fine and medium rice, indicating that coarse rice had comparatively smaller influence on the allocation of land for rice production. The main reason is that farmers always expect good market price from the produced crop. The market price of fine and medium rice had increased more rapidly than coarse rice. As a result, the crop area for fine and medium rice has increased more rapidly than that for coarse rice area.

\section{Time trend}

Time trend mainly represents the availability of suitable technology for crop production. The coefficients of time trend in the regression models of wholesale price of fine and medium rice had significant positive impacts on the allocation of land for rice production. These results indicate that time trend had positive impact for wholesale price on the allocation of land for rice production.

The coefficients of multiple determination $\left(\mathrm{R}^{2}\right)$ was found to vary from 96 to 98 per cent which indicate that the fitted equations explained about more than 95 per cent of the variation in the allocation of area for rice production. The F-test was used to determine the significance level of $\mathrm{R}^{2}$, which were found significant at 1 per cent level.

\subsubsection{Wheat production}

The lagged acreage, yield and time trend on the allocation of land for wheat is presented in Table
3, which shows that all the coefficients in the regression model had expected signs except lagged price. The coefficients of lagged acreage, lagged price and lagged yield had significant impacts (significant at 1 per cent level) on the allocation of wheat production. The coefficient of time trend had negative impact on the allocation of land for wheat production and it was not statistically significant. This indicates that the allocation of land for wheat production has decreased over the year eventhough the wholesale market price has increased.

\subsection{Short-run (SR) and long-run (LR) elasticity and price variability}

The estimates of price elasticity and price variability of wholesale price for fine, medium and coarse rice are presented in Table 4. The estimates of SR elasticity of price for fine and medium rice were found quite low, which indicate that an increase in the price would bring a small increase in the amount of land for fine and medium rice in case of wholesale price. However, the estimates of LR elasticity of fine and medium rice were quite high; indicating the allocation of land for fine and medium rice to have increased rapidly in the long-run compared to short-run.

Coefficient of variation (COV) of price was used as price variability, as mentioned before. The coefficients of variation (COV) were 85 per cent and 87 per cent for SR and LR, respectively, which indicate that the price variability had also significant impact on the allocation for land for rice production.

The estimates of price elasticity and price variability of retail price for wheat are presented in Table 5. The estimates of SR elasticity of price of wheat were found quite low. These results also support the conclusion considering that of wholesale and retail price of wheat. 
Table 3. Estimates of regression coefficients of wholesale prices of wheat

\begin{tabular}{lcccc}
\hline & Coefficients & & Coefficients \\
\cline { 1 - 2 } Constant & $0.0053350 * * *$ & & $\ln \mathrm{Y}_{\mathrm{t}-1}$ & $0.00001135^{* * *}$ \\
& $(28.14)$ & & & $(0.34)$ \\
$\ln \mathrm{A}_{\mathrm{t}-1}$ & $0.999330^{* * *}$ & & $\ln$ time & -0.00000229 \\
& $(10.94)$ & & $(-1.57)$ \\
$\ln \mathrm{P}_{\mathrm{t}-1}$ & $0.00009292^{* *}$ & & $\mathrm{R}^{2}$ & 0.99 \\
& $(3.69)$ & & \\
\hline
\end{tabular}

Notes:

(i) $* * *$ and $* *$ indicate $1 \%$ and $5 \%$ level of significance, respectively.

(ii) The figures in parentheses indicate t-statistic.

(iii) A, P and Y indicate cropped area, price and yield, respctively.

Table 4. Estimates of SR and LR elasticities of wholesale price of rice and price variability

\begin{tabular}{|c|c|c|c|c|c|}
\hline \multirow[b]{3}{*}{ Types of rice } & \multirow[b]{3}{*}{$\begin{array}{l}\text { Co-efficients of } \\
\text { adjustments }\end{array}$} & \multicolumn{4}{|c|}{ Estimates of elasticity with respect to } \\
\hline & & \multicolumn{2}{|c|}{ Price } & \multicolumn{2}{|c|}{ Price Variability (CV\%) } \\
\hline & & $\begin{array}{l}\text { Short-run } \\
\quad(\mathrm{SR})\end{array}$ & $\begin{array}{l}\text { Long-run } \\
\text { (LR) }\end{array}$ & $\begin{array}{l}\text { Short-run } \\
\quad(\mathrm{SR})\end{array}$ & $\begin{array}{l}\text { Long-run } \\
\text { (LR) }\end{array}$ \\
\hline Fine rice & 0.4195 & -0.263 & -0.6269 & & \\
\hline Medium rice & 0.3663 & -0.3015 & -0.8230 & $85 \%$ & $87 \%$ \\
\hline Coarse rice & 0.3874 & -0.0047 & -0.01213 & & \\
\hline
\end{tabular}

Table 5. Estimates of SR and LR elasticities of wholesale price of wheat and price variability

\begin{tabular}{|c|c|c|c|c|c|}
\hline \multirow[b]{3}{*}{ Crop } & \multirow[b]{3}{*}{$\begin{array}{c}\text { Co-efficients of } \\
\text { adjustments }\end{array}$} & \multicolumn{4}{|c|}{ Estimates of elasticity with respect to } \\
\hline & & \multicolumn{2}{|c|}{ Price } & \multicolumn{2}{|c|}{ Price Variability (CV\%) } \\
\hline & & $\begin{array}{l}\text { Short-run } \\
\quad(\mathrm{SR})\end{array}$ & $\begin{array}{l}\text { Long-run } \\
\text { (LR) }\end{array}$ & $\begin{array}{l}\text { Short-run } \\
\text { (SR) }\end{array}$ & $\begin{array}{l}\text { Long-run } \\
\text { (LR) }\end{array}$ \\
\hline Wheat & 0.00067 & 0.00009292 & 0.1386 & $56 \%$ & $60 \%$ \\
\hline
\end{tabular}




\section{Conclusions}

The present study has assumed the impacts of price and price variability on acreage allocation in food grain production in Bangladesh. The findings of the study show that the coefficients of trend variable were observed negative for wheat production that has shown a downward shift in the allocation of land for rice and wheat production. However, the coefficients of time trend variable were observed positive for wholesale price of all types of rice that showed an upward shift in allocation of land for of all types of rice production. The values of Nerlovian coefficient of adjustment were found low which means that although the farmers were adjusting to the changing levels of price, price variability, yield, etc., yet the adjustment was not rapid. Thus, it may be concluded that price of rice and wheat should be adjusted rapidly along with appropriate allocation of rice and wheat production otherwise farmers will convert paddy and wheat fields into other crops fields that will hinder food grain production in Bangladesh.

\section{References}

Acharya, S. S., Bhatia, S. 1974. Acreage response to price, yield and rainfall changes in Rajastant. Agricultural Situation in India, 29(4): 209-217.

Ahmed, R., and Bernard, A. 1989. Rice price fluctuation and an approach to price stabilization in Bangladesh, Washington, D.C.: IFPRI, Research Report No.72. http://www.ifpri.org/sites/default/files/publi cations/rr72.pdf (Cited date - February, 2010)

Alam, S. 1992. Rice yield growth scenario and the factors contributing to output changes of different varieties and types in Bangladesh. The Bangladesh Journal of Agricultural Economics, 15(2): 19-33.

Barmon, B. K., Kondo, T. and Osanami, F. 2007. Economic evaluation of rice-prawn gher farming system on soil fertility for modern variety of rice production in Bangladesh. Asia-Pacific Journal of Rural Development (APJORD), 17(1):67-81.

BBS, 1996. Bangladesh Bureau of Statistics. Statistical Yearbook of Bangladesh. Planning Division, Ministry of Planning, Government of the People's of Bangladesh, 448-49 pp.

BBS, 2005. Bangladesh Bureau of Statistics. Statistical Yearbook of Bangladesh. Planning Division, Ministry of Planning, Government of the People's of Bangladesh, 464-65 pp.

BBS, 2009. Bangladesh Bureau of Statistics. Statistical Yearbook of Bangladesh. Planning Division, Ministry of Planning, Government of the People's of Bangladesh, 421-23 pp.

BER, 2011. Bangladesh Economic Review. Economic Adviser's Wing, Finance Division, Ministry of Finance, Government of the People's Republic of Bangladesh, 91 p.

Devi, P. K., Rajagopalan, R. 1965. Price and acreage response: a case study of groundnut in North Arcot district. Indian Journal of Agricultural Economics, 20(1):31-35.

Dey, M. M., Miah, M. N. I., Mustsfi, B. A. A. and Hossain, M. 1996. Rice Production Constraints in Bangladesh: Implications for Further Research Priorities. In: Rice research in Asia: Progress and Priorities, (ed.) R. E. Evenson, R. W. Herdt, and M. Hossain, CAB INTERNATIONAL in association with the International Rice Research Institute (IRRI), Printed and bound in the UK, University Press, Cambridge, 171-191 pp.

Dorosh, P., and Shahabuddin, Q. 2002. Rice price stabilization in Bangladesh: An analysis of policy options, MSSD Discussion Paper no. 46, Structural Studies Division International Food Policy Research Institute 2033 K Street, N.W. Washington, D.C. 20006 U.S.A. 
http://www.ifpri.org/sites/default/files/publi cations/mssdp46.pdf. (Cited date - June 20, 2010).

Kaul, J. L. 1967. A study of supply response to price of Punjab crops. Indian Journal of Agricultural Economics, 48(18):25 - 39.

Kaul, J. L. and Sidhu, D. S. 1970. Acreage response to prices for major crops in Punjab - an econometric study. Indian Journal of Agricultural Economics, 26(1):37-52.

Lalit, S. and Kahlon, A. S. 1969. Estimation of acreage response to price of selected crops in Punjab State. Indian Journal of Agricultural Economics, 20(1):20-25.

Nerlove, M., 1958. The Dynamics of Supply, John Hopkins Press, Baltimore, pp.63-70.

Quasem, M. A. 2011. Conversion of Agricultural Land to Non-agricultural Uses in Bangladesh: Extent and Determinants. Bangladesh Development Studies, 34 (1):59-85.
Rao, M. S. and Krisna, J. 1965. Price expectation and acreage response for wheat in Uttar Pradesh. Indian Journal of Agricultural Economics, 24(3):46 - 49.

Sahay, K. K. 1971. Acreage response of groundnut in major groundnut zones - a study in the dynamics of supply. Agricultural Situation in India, 26(7):477481.

Shahabuddin, Q. 1992. A disaggregated model for stabilization of rice prices in Bangladesh. The Bangladesh Development Studies, 20(1):1-41.

Singh, I. J. and Kumar, P. 1976. Impact of rice price and price variability on acreage allocation in Haryana. Indian Journal of Agricultural Economics, 34(3):1-18.

Singh, R. D., Singh, D. and Rao, P. R. 1974. Estimations of agriculture acreage response relationship: Some methodological issues. Journal of Agricultural Economics, 29(1):26-38. 